\title{
Murine Cytomegalovirus-associated Pneumonitis in the Lungs Free of the Virus
}

\author{
Kazuo Tanaka, ${ }^{\star}$ Yasuhiro Koga, ${ }^{\mathbf{f}}$ Yi-Yu Lu, ${ }^{\ddagger}$ Xing-Ying Zhang, ${ }^{\ddagger}$ Ye Wang, ${ }^{\ddagger}$ Genki Kimura, ${ }^{\star}$ and Kikuo Nomoto ${ }^{\ddagger}$ \\ Departments of *Virology and ${ }^{\ddagger}$ Immunology, Medical Institute of Bioregulation, Kyushu University, Fukuoka 812, Japan; and \\ ${ }^{8}$ Department of Infectious Disease, Tokai University School of Medicine, Isehara 259-11, Japan
}

\begin{abstract}
At 4 wk after intraperitoneal inoculation of murine cytomegalovirus (MCMV) in adult BALB/c mice, MCMV remained detectable only in the salivary glands. When $T$ cells of these mice were activated by a single injection of antiCD3e monoclonal antibody, mice died of interstitial pneumonitis at 24-48 $\mathrm{h}$ after injection, accompanied by elevation of serum levels of TNF- $\alpha$ and IFN- $\gamma$. However, MCMV remained undetectable in the lungs during the period. Simultaneous injection of cyclosporin A reduced such effects of anti-CD3. In conclusion, although the presence of MCMV in the host may be required, MCMV-associated pneumonitis is not mediated by virus in the lung but probably by the cytokines released from $T$ cells, of which responsiveness to stimulation via CD3 molecule has been presumably modified by MCMV infection. (J. Clin. Invest. 1994. 94:1019-1025.) Key words: cytomegalovirus - pneumonitis - immunosuppression $\bullet$ cytokine release syndrome $\bullet$ persistent viral infection
\end{abstract}

\section{Introduction}

Human cytomegalovirus (CMV) ${ }^{1}$ causes pneumonitis, retinitis, gastroenteric diseases, hepatitis, and encephalitis in immunomodulated or immunocompromised patients. Among them, pneumonitis is a serious concern because of its high frequency of occurrence, its high mortality, and lack of effective antiviral therapy. Murine CMV (MCMV) infection in mice resembles its human counterpart in many ways with respect to establishment of acute and chronic infections, viral persistency and latency, and host-virus interaction (1). Recent results of studies on MCMV-associated pneumonitis in mice from several laboratories suggest that the presence of replicating MCMV alone in the lungs is not responsible for MCMV pneumonitis (2-4). Unirradiated F1 hybrid mice infected with MCMV develop se-

Address correspondence to Kazuo Tanaka, M.D., Ph.D., Department of Virology, Medical Institute of Bioregulation, Kyushu University 69, 31-1 Maidashi, Higashi-ku, Fukuoka 812, Japan.

Received for publication 8 November 1993 and in revised form 4 April 1994.

1. Abbreviations used in this paper: CMV, cytomegalovirus; CsA, cyclosporin $\mathrm{A} ; \mathrm{GvH}$, graft-versus-host; MCMV, murine cytomegalovirus; PFU, plaque forming unit; $\mathrm{SaO}_{2}$, oxygen saturation ratio in the arterial blood; TCR, $\mathrm{T}$ cell receptor.

J. Clin. Invest.

(C) The American Society for Clinical Investigation, Inc. 0021-9738/94/09/1019/07 \$2.00

Volume 94, September 1994, 1019-1025 vere interstitial pneumonitis, when adoptively transferred with spleen cells of an uninfected parental mouse strain (2). However, MCMV injection alone or induction of graft-versus-host (GvH) reaction alone, in F1 mice, does not lead to pneumonitis, even though the amount of virus in the lungs of the mice given with MCMV-induced GvH is similar to that in mice given MCMV alone (2), suggesting that viral replication per se is not sufficient for the development of MCMV pneumonitis, and that events associated with immune response or immune reaction (severe GvH reaction, in this case) are required. When BALB/c mice are treated with a single dose of cyclophosphamide after MCMV infection, pneumonitis is induced, whereas it is not induced in severely immunosuppressed mice, who received continuous injections of cyclophosphamide, in spite of the presence of high titer of MCMV in the lungs (3). In addition, athymic nude mice who receive MCMV do not develop pneumonitis, even though there is extensive replication of the virus (4). Though MCMV is detectable in the lungs in all of these situations, all these results suggest that MCMV pneumonitis is not directly related to the ongoing MCMV replication in the lungs and raise a possibility that the systemic activation of host $\mathrm{T}$ cells, perhaps manifested by cytokine(s), may induce the pathogenic events for MCMV pneumonitis. To examine whether MCMV pneumonitis can occur in the absence of ongoing viral replication in the lungs, we use, in the present study, a mouse model of MCMV persistent infection, where MCMV does not exist in organs except the salivary gland, and T cells were activated by injection of anti-mouse CD3 monoclonal antibody.

\section{Methods}

\section{Mice}

Male BALB/c mice were provided from and bred in the Kyushu University Animal Center (Fukuoka, Japan). Mice were bred in isolated cages.

\section{Virus and virus titration}

Smith strain of MCMV was obtained from the American Type Culture Collection (Rockville, MD) and passed once in the primary culture of mouse embryo cells, which were prepared from 15- to 19-d-old BALB/c embryo and confirmed the absence of mycoplasma. The homogenate of infected mouse embryo cells was injected intraperitoneally to male $\mathrm{BALB} / \mathrm{c}$ mice. At $2 \mathrm{wk}$ after infection, the salivary glands were collected and supernatants of their homogenates were used as MCMV stock suspension. To determine tissue virus titer, organs were frozen, thawed, and homogenated in Eagle's minimal essential medium (Gibco Laboratories, Grand Island, NY) supplemented with $10 \%$ fetal calf serum, $10 \mathrm{mM}$ Hepes, penicillin $(500 \mathrm{U} / \mathrm{ml})$, and streptomycin $(0.1 \mathrm{mg} / \mathrm{ml})$. The homogenates were titrated in $\log _{10}$ dilutions on subconfluent $3 \mathrm{~T} 3 / \mathrm{Swiss}$ albino cells in culture dishes $(35 \times 10 \mathrm{~mm}$; Nunc, Roskilde, Denmark) and incubated for $90 \mathrm{~min}$. Thereafter, monolayers were covered with methylcellulose, and plaques were counted $6 \mathrm{~d}$ later. Detection level of this assay was defined as 12.5 plaque forming units (PFU)/organ. Virus concentration of the MCMV stock suspension was $5 \times 10^{7} \mathrm{PFU} / \mathrm{ml}$. $\mathrm{LD}_{50}$ for adult BALB/c mouse after intraperitoneal inoculation was 5 
$\times 10^{6}$ PFU. Supernatants of the homogenates of the salivary glands from noninfected mice were used as a control for mock infection.

\section{Monoclonal antibodies}

Antibodies against mouse CD3 $\epsilon$ (hamster IgG, clone 145-2C11) and mouse T cell receptor (TCR) $\beta$ (hamster IgG, clone H-57-597) were obtained by growing hybridoma cells in serum-free medium (SFM-101; Nissui, Tokyo, Japan). Antibodies were concentrated and purified by $50 \%$ ammonium sulfate precipitation. The purity of the preparations was confirmed by SDS-PAGE, and concentration of antibodies was determined by dye-binding assay using a protein-assay kit (Bio-Rad Laboratories, Richmond, CA).

\section{Detection of MCMV DNA in the organ}

DNA extraction from organs. Organs were removed, minced, and transferred into $4.5 \mathrm{ml}$ of TNE buffer, which is composed of $10 \mathrm{mM}$ Tris$\mathrm{HCl}(\mathrm{pH} 7.5), 100 \mathrm{mM} \mathrm{NaCl}$, and $1 \mathrm{mM}$ EDTA. Then, 0.5\% SDS and $5 \mathrm{mg} / \mathrm{ml}$ of proteinase K (Sigma Chemical Co., St. Louis, MO) were added. Samples were incubated for $18 \mathrm{~h}$ at $37^{\circ} \mathrm{C}$ in a shaking water bath. DNA was isolated by standard procedures, including phenol/chloroform extraction and ethanol precipitation. The amount of purified DNA was determined from the optical density at $260 \mathrm{~nm}$.

Analysis of PCR-amplified DNA. $1 \mu \mathrm{g}$ of DNA from the organ was enhanced by PCR using two oligonucleotide primers which were selected from MCMV immediate-early gene 1 from published sequence data $(5,6)$. The base sequences were as follows: primer $1(1701-$ 1730), 5'-ATC-AAT-CAG-CCA-TCA-ACT-CTG-CTA-CCA-ACA-3'; and primer 2 (2400-2371 [antisense]), 5'-ATG-GTG-AAG-CTA-TCAAAG-ATG-TGC-ATC-TCA-3' . A 30-bp oligonucleotide complementary to a sequence $(1801-1830)$ lying between the primers was used as a probe. PAMB 25, which contains the full length of MCMV immediateearly gene (7), was used for positive controls. $100-0.1 \mathrm{pg}$ of pAMB25 was mixed with $1 \mu \mathrm{g}$ of DNA from the lung of MCMV-negative mice, to exclude the possibility that some contaminant in the organ DNA preparation might be inhibiting PCR reaction. The PCR was performed in an automated thermal cycler (program temperature control system PC-500; Astec, Fukuoka, Japan) after addition of Taq polymerase (Perkin-Elmer Cetus Corp., Norwalk, CT). PCR-amplified samples were electrophoresed on $2 \%$ agarose gel and stained with ethidium bromide at $100 \mathrm{~V}$ for $2 \mathrm{~h} . \phi \mathrm{X} 174 / \mathrm{HaeIII}$ digest was used as a marker. Southern transfer was done onto GeneScreen Plus hybridization transfer membrane (Dupont/New England Nuclear, Boston, MA). Hybridization was performed for $2 \mathrm{~h}$ at $42^{\circ} \mathrm{C}$ with the probe tailed at the $3^{\prime}$ end with fluorescein dUTP, which was detected by chemiluminescence (ECL system; Amersham International, Buckinghamshire, UK). As a technical control of PCR experiments, mouse $\beta$-actin DNA was amplified using commercially available primers and a probe (Genemed Biotechnologies, Inc., San Francisco, CA) (BAC-103 and -104 for primers and BAC202 for a probe). The $\mathrm{PCR}$ products were quantitated by densitometric scanning with a densito-pattern analyzer (EPA-3000; Maruzen Oil Chemical, Tokyo, Japan).

Determination of serum levels of TNF- $\alpha$, IFN- $\gamma$, and IL-2 Serum levels of TNF- $\alpha$, IFN- $\gamma$, and IL-2 were measured by ELISA using commercial kits (Genzyme Corp., Cambridge, MA). Sera collected from individual mice were stocked at $-80^{\circ} \mathrm{C}$ until the assay.

\section{Blood chemistry}

Serum levels of alkaline phosphatase, glutamate oxaloacetate transaminase, glutamate pyruvate transaminase, total bilirubin, blood urea nitrogen, and creatinine were quantified by $p$-nitrophenyl phosphate assay, Karmen's method, Wroblenski-La due's method, alkaline azo-bilirubin assay, urease-GIDH assay, and Jaffe's method, respectively, using an autoanalyzer (model 736-10; Hitachi Ltd., Tokyo, Japan).

\section{Light microscopy}

Organs were removed after exsanguination and fixed in $3.7 \%$ formaldehyde at room temperature for $18 \mathrm{~h}$. Sections were stained with hematoxylin-eosin.
Table I. Death of Mice Persistently Having Detectable MCMV Only in the Salivary Glands after Injection with Anti-T Cell Monoclonal Antibody*

\begin{tabular}{cccc}
\hline & & \multicolumn{2}{c}{ Mortality } \\
\cline { 4 - 4 } mAb $^{\ddagger}$ (specificity) & $\begin{array}{c}\text { Injection } \\
\text { dose }\end{array}$ & MOCK & MCMV \\
\hline & $\mu g$ & & \\
$145-2 \mathrm{C} 11$ (mouse CD3 $\epsilon)$ & 20 & $0 \%(0 / 14)$ & $33 \%(7 / 21)$ \\
& 50 & $0 \%(0 / 14)$ & $60 \%(24 / 40)$ \\
& 100 & $0 \%(0 / 10)$ & $63 \%(15 / 24)$ \\
& 200 & $0 \%(0 / 10)$ & $93 \%(14 / 15)$ \\
H57-597 (mouse TCR $\beta$ ) & 20 & $0 \%(0 / 7)$ & $0 \%(0 / 8)$ \\
& 200 & $0 \%(0 / 10)$ & $0 \%(0 / 10)$
\end{tabular}

$* \mathrm{BALB} / \mathrm{c}$ mice were inoculated intraperitoneally with $1 \times 10^{5} \mathrm{PFU}$ $\left(0.02 \mathrm{LD}_{50}\right)$ of MCMV or homogenate of the salivary glands from noninfected mice (MOCK) $4 \mathrm{wk}$ before. Death was determined at 24$48 \mathrm{~h}$ after injection of varying doses of $\mathrm{mAb}$, since mice which survived such a critical period did not die within the observation period of several weeks. ${ }^{\ddagger}$ Hybridomas were cultured in serum-free culture medium (SFM-101; Nissui), and supernatants were collected. Immunoglobulin was partially purified by ammonium sulfate fractionation, and purity was confirmed by SDS-PAGE. mAb was diluted with saline and injected intraperitoneally. ${ }^{8}$ Mortality, percentage (number of mice died per number of mice injected with mAb). Death occurred during the period of 24-48 $\mathrm{h}$ after injection of $\mathrm{mAb}$

\section{Measuring of oxygen saturation ratio of arterial blood $\left(\mathrm{SaO}_{2}\right)$}

Under diethylether anesthesia, two probes of oxygen saturation monitor (Pulsox 5; Amco Ltd., Tokyo, Japan) were bilaterally stuck on the thigh of a mouse. After confirmation of arterial pulsation in the femoral artery, $\mathrm{SaO}_{2}$ was monitored.

\section{Statistical analysis}

Statistical analysis was done with Student's $t$ test.

\section{Results}

Male BALB/c mice at $6 \mathrm{wk}$ of age were inoculated intraperitoneally with $1 \times 10^{5} \mathrm{PFU}\left(0.02 \mathrm{LD}_{50}\right)$ of MCMV. A high titer of MCMV was noted in the salivary glands even at 4 wk after inoculation $\left(2.2 \times 10^{3} \mathrm{PFU}\right)$. In the spleen and the lungs, infectious MCMV was detected at 10 and $15 \mathrm{~d}$ after inoculation, respectively, and it became undetectable by plaque assay ( $<12.5$ PFU/organ) and by PCR (see below) at 4 wk after inoculation. In the thymus and bone marrow, no virus was detected by plaque assay even at $5 \mathrm{~d}$ after inoculation.

These persistently infected mice were injected intraperitoneally with anti-CD3 $\epsilon$ monoclonal antibody (anti-CD3 mAb, clone $145-2 \mathrm{C11}$, hamster Ig) to activate T cells in vivo (8). The mice persistently infected with MCMV showed piloerection and hypomotility beginning at $\sim 24 \mathrm{~h}$ after injection of anti-CD3 and died at times between 24 and $48 \mathrm{~h}$ with mortalities depending on the dose of anti-CD3 (Table I). Even with the highest dose of anti-CD3 $(200 \mu \mathrm{g})$, mice of mock infection did not die and showed only slight piloerection and hypomotility followed by gradual restoration, whereas the same dose of anti-CD3 killed 93\% of the mice infected persistently with MCMV. Pretreatment with ultraviolet irradiation of MCMV inoculum abrogated 
both the establishment of persistent infection and killing by anti-CD3, suggesting that live virus in the inoculum is necessary. mAb against TCR $\beta$ chain (H57-597) was found to have no killing activity upon the persistently infected mice, in spite of its similar mitogenic activity on $\mathrm{T}$ cells as anti-CD3 mAb. The reason for the discrepancy between anti-CD3 $\epsilon$ and antiTCR is unclear. It must be mentioned that, since H57-597 shares the same immunoglobulin isotype (IgG of hamster origin) with $145-2 \mathrm{C} 11$, the injection of xenoprotein is not responsible for the observed anti-CD3-induced death of mice.

Possible enhancement or induction of replication of MCMV in the salivary glands and other organs was examined at 0 and $48 \mathrm{~h}$ after anti-CD3 $(50 \mu \mathrm{g})$ injection by plaque assay of the organ extracts. In the salivary glands, MCMV titer at $48 \mathrm{~h}$ after anti-CD3 injection $\left(2.2 \pm 0.4 \times 10^{3}, n=5\right)$ was comparable with that at $0 \mathrm{~h}\left(2.9 \pm 0.7 \times 10^{3}, n=5\right)$. In the spleen and the lungs, MCMV was not detected by plaque formation at $0 \mathrm{~h}$ and even at $48 \mathrm{~h}$. To examine the possible existence of MCMV with levels below the detection level of plaque assay, PCR was used to detect a low copy of viral DNA in the organs. DNA was extracted from the lungs and the spleen of mice persistently infected with MCMV in the salivary glands at 0 and $48 \mathrm{~h}$ after anti-CD3 injection (50 $\mu \mathrm{g})$, and the sequence of the major immediate-early gene of MCMV was amplified, and its copies were calculated. As shown in Fig. 1, MCMV DNA was not detectable in the lungs and the spleen even after anti-CD3 mAb injection with a detection limit of $0.1 \mathrm{pg}$ of pAMB25, which represents $10^{4}$ copies of the sequence. On the other hand, high copy numbers of MCMV DNA was noted in the salivary glands. As a control of the technical efficacy of PCR amplification, a sequence of the cellular mouse $\beta$-actin gene was amplified from the same DNA preparation. With a detection limit of $1 \mathrm{ng}$, the amplification efficacy for the cellular test gene was almost the same for lung, spleen, and salivary gland DNA (data not shown). This result excluded the influence of the DNA organ source on the technical amplification efficacy.

$\mathrm{T}$ cell stimulation by anti-CD3 $\mathrm{mAb}$ has been known to trigger the release of several cytokines both in clinical practice and animal models. These phenomena have been referred to as cytokine release syndrome or cytokine-related first injection syndrome (9). Present findings of piloerection or hypomotility observed in the mice persistently infected with MCMV after anti-CD3 injection resemble the mice exhibiting cytokine release syndrome (10). We found in the present study that systemic adverse reactions (piloerection, hypomotility, and death) were seen only after the first injection of anti-CD3 mAb, and none of the survivors after the first injection of mAb exhibited these findings and died upon the second injection of anti-CD3 mAb (data not shown). After anti-CD3 injection, serum levels of TNF- $\alpha$ were elevated at $12 \mathrm{~h}$, and those of IFN- $\gamma$ were elevated at $6-12 \mathrm{~h}$ in the mice persistently infected with MCMV compared with their serum levels in mock infected mice. There was no difference in IL-2 levels between the two groups (Fig. $2 \mathrm{~A}$ ). When $10 \mathrm{mg} / \mathrm{kg}$ of cyclosporin A (CsA), an inhibitor of cytokine production $(11,12)$, was simultaneously injected with anti-CD3 mAb to the mice persistently infected with MCMV on the day before and the day of anti-CD3 injection $(50 \mu \mathrm{g})$, serum levels of TNF- $\alpha$, IFN- $\gamma$, and IL- 2 were significantly lower at $12 \mathrm{~h}$ after $\mathrm{mAb}$ injection than those in mice injected with anti-CD3 alone (Fig. $2 \mathrm{~B}$ ). The mortality rate was also reduced from $42(n=12)$ to $10 \%(n=10)$.

Which organ serves as the target for cytokine-mediated fatal

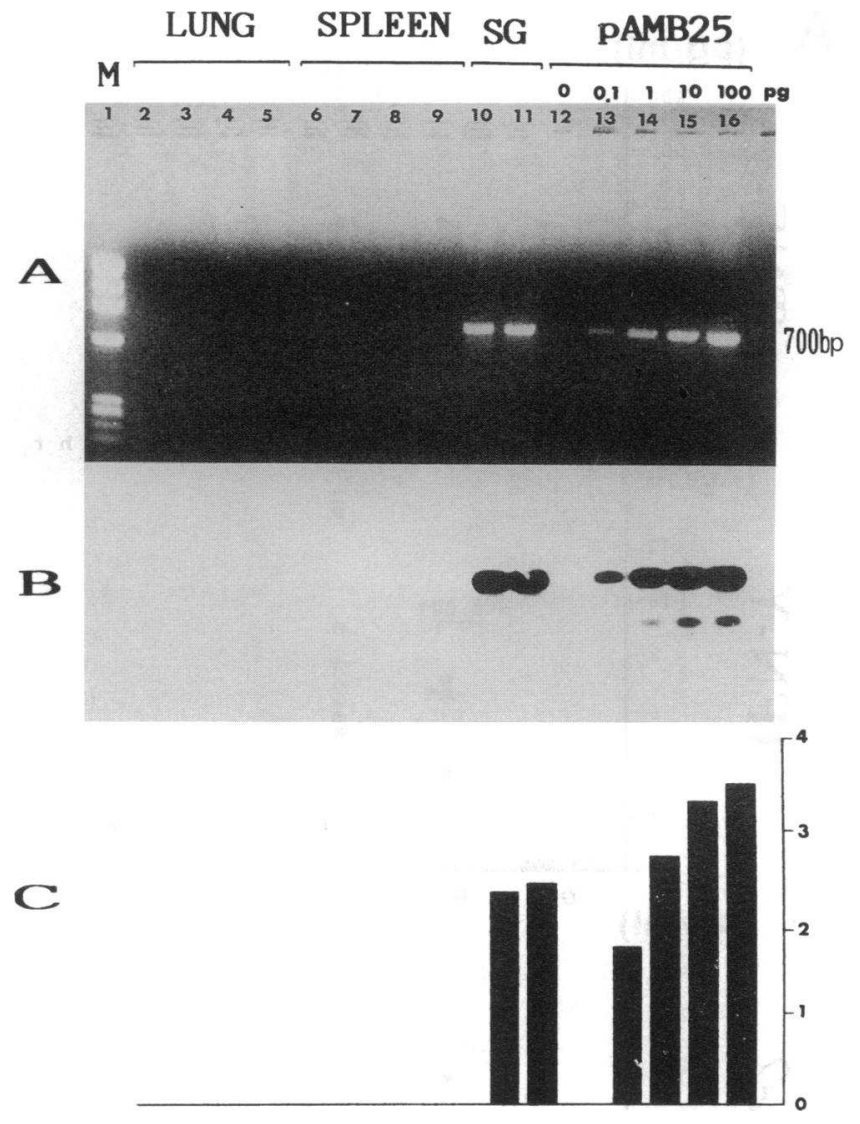

Figure 1. Absence of detectable MCMV DNA in the lungs and the spleen by PCR for the major immediate-early gene sequence of viral DNA. Mice which had been inoculated intraperitoneally with $1 \times 10^{5}$ PFU $\left(0.02 \mathrm{LD}_{50}\right)$ of MCMV 4 wk before were treated by injection with $50 \mu \mathrm{g}$ of anti-CD3 mAb. The lung (lanes 2-5), the spleen (lanes 6-9), and the salivary glands (lanes 10 and 11 ) were removed at $0 \mathrm{~h}$ (lanes 2 and 3,6 and 7, and 10) and at $48 \mathrm{~h}$ (lanes 4 and 5,8 and 9, and 11) after the mAb injection, and DNA was extracted. $1 \mu \mathrm{g}$ of DNA from the organ was enhanced by PCR using two oligonucleotide primers which were selected from MCMV immediate-early gene 1. A 30-bp oligonucleotide complementary to a sequence lying between the primers was used as a probe. 100-0.1 pg of pAMB 25 , which contains the full length of MCMV immediate-early gene, mixed with $1 \mu \mathrm{g}$ of DNA from the lung of uninfected mice was used for positive controls (lanes 1216). Lane 1, marker; $\phi X 174 / \mathrm{HaeIII}$ digest. (A) Agarose gel electrophoresis stained with ethidium bromide; $(B)$ the corresponding Southern blot filter hybridized by the probe labeled with ECL system; and $(C)$ the corresponding densitometric scanning. Optical absorbance of lanes $10-16$ was $2.43,2.49,0,1.72,2.73,3.40$, and 3.51 , respectively.

reaction? Mean serum levels of alkaline phosphatase, glutamate oxaloacetate transaminase, glutamate pyruvate transaminase, total bilirubin, blood urea nitrogen, and creatinine were $111 \mathrm{U} /$ dl, $302 \mathrm{U} / \mathrm{dl}, 282 \mathrm{U} / \mathrm{dl}, 0.5 \mathrm{mg} / \mathrm{dl}$, and $0.2 \mathrm{mg} / \mathrm{dl}$, respectively $(n=4)$, probably ruling out the possibility of occurrence of acute hepatic failure and acute renal failure. Histological examinations show that there were no positive findings to explain the cause of death in the thymus, the spleen, the liver, or the kidney (Fig. $3 \mathrm{~A}$ ). In the thymus, the nuclei of a large fraction of cells in the cortex were fragmented (13). However, nuclear fragmentation of thymocytes itself is by no means fatal to the host, though it may be related to elevated serum levels of cyto- 


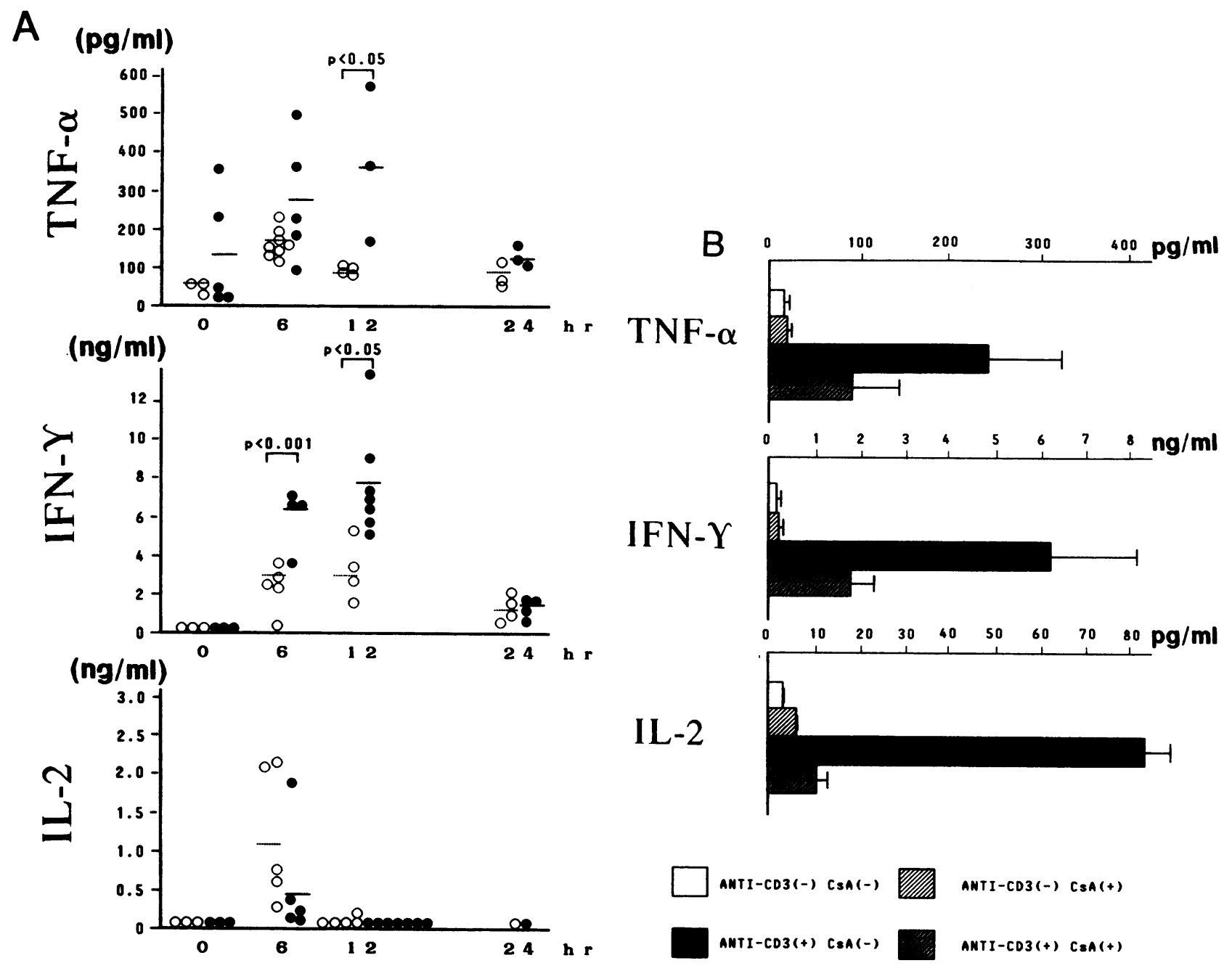

Figure 2. Elevation of serum levels of TNF- $\alpha$ and IFN- $\gamma$. Serum levels of TNF- $\alpha$, IFN- $\gamma$, and IL-2 were measured by ELISA. (A) Mice, which had been inoculated intraperitoneally with (filled circles) or without MCMV (open circles) 4 wk earlier, were injected intraperitoneally with $20 \mu \mathrm{g}$ of anti-CD3 mAb. Serum was collected at various intervals after anti-CD3 injection as indicated in the figure. $(B)$ Mice, which had been inoculated with MCMV 4 wk earlier, were injected intraperitoneally with anti-CD3 $(20 \mu \mathrm{g}$, at $0 \mathrm{~h})$ together with or without CsA. CsA $(10 \mathrm{mg} / \mathrm{kg})$ was administered at $-24 \mathrm{~h}$ and then at $0 \mathrm{~h}$. Serum was collected at $6 \mathrm{~h}$ for measuring of cytokines.

kines (14). In the spleen, destruction of lymphofollicles was noted, suggesting that some drastic events occur in response to anti-CD3 injection only in MCMV-infected mice. In the liver, although small necrotic lesions were seen, almost all of the liver cells remained intact. In the kidney, no pathological change was seen. In the lungs, however, histologically severe abnormalities were seen at $48 \mathrm{~h}$ after anti-CD3 injection in the mice persistently infected with MCMV (Fig. $3 \mathrm{~B}$, bottom right). Marked thickening of alveolar septae with cellular infiltrations mainly with mononuclear cells and accumulation of amorphous material were observed (Fig. $3 \mathrm{~B}$, inset). As a result, diminution of alveolar spaces was noted. Additionally, no bleeding or emphysema was noted, and airways were kept intact. Although these histological findings were reported as histological characteristics of MCMV-associated interstitial pneumonitis (3), MCMV or its DNA could not be detected in the lungs as mentioned above (Fig. 1). These morphological changes correlate to defective pulmonary function; $\mathrm{SaO}_{2}$ in the femoral artery determined by a pulse oxymetry was significantly lower than that in uninfected controls at $24-48 \mathrm{~h}$ after injection of $50 \mu \mathrm{g}$ of anti-CD3
$(78.8 \pm 10.7$ vs $89.5 \pm 1.3 \%, n=10, P<0.01)$. These results indicate that mice with MCMV died of disturbance of ventilation, caused by MCMV-associated pneumonitis in "MCMVfree" lung. It is further suggested that these changes in the lungs may be mediated by cytokine(s) as mentioned above; that is to say, MCMV-associated pneumonitis might be one of the manifestations of cytokine release syndrome. This notion was further supported by the results shown in Fig. 2 B. Simultaneous injection of CsA with anti-CD3 mAb to the mice persistently infected with MCMV lowered serum levels of cytokines than those in mice injected with anti-CD3 alone (Fig. $2 B$ ), and remarkably diminished the cellular infiltrates to the alveolar septae (data not shown). As mentioned above, the mortality rate was also reduced from 42 to $10 \%$ by CsA treatment.

\section{Discussion}

The present indication that MCMV pneumonitis is mediated not by the presence of the virus in the lung but possibly by cytokines is supported by some clinical data. CMV pneumonitis 


\section{A KIDNEY}
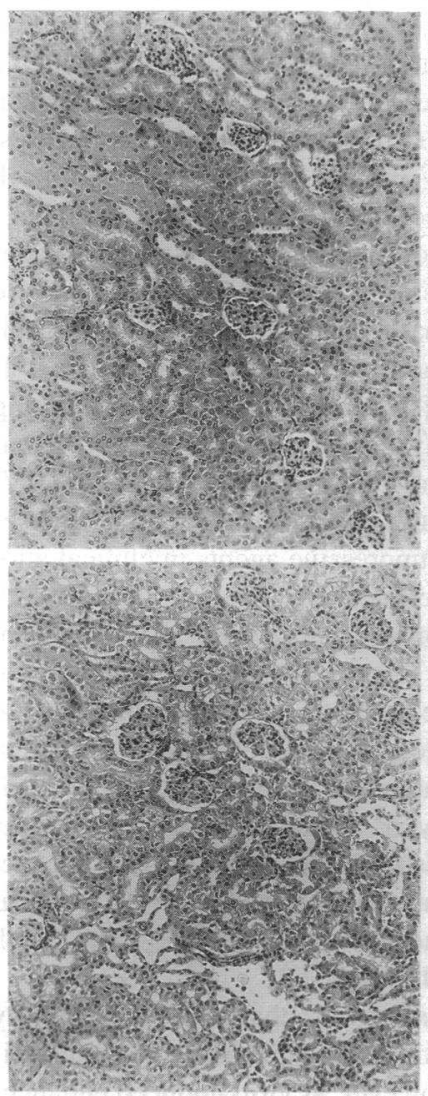

LIVER
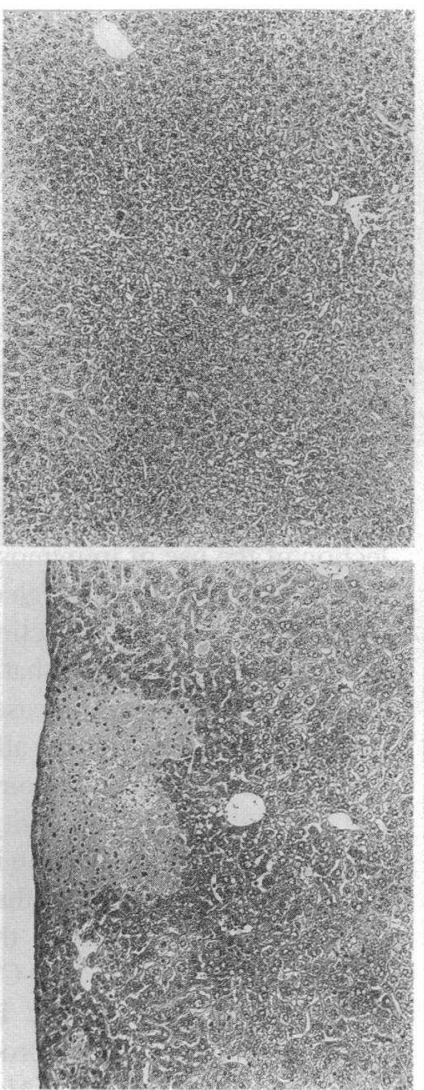

SPLEEN
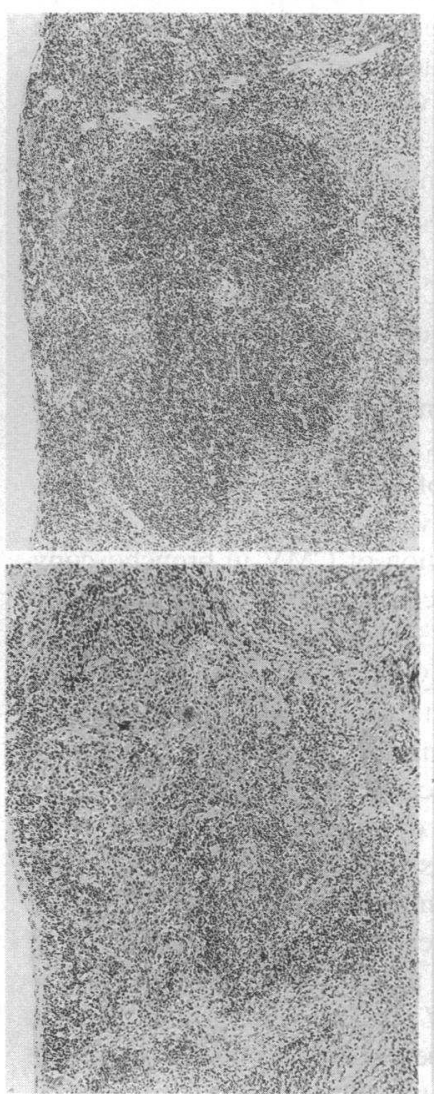

THYMUS
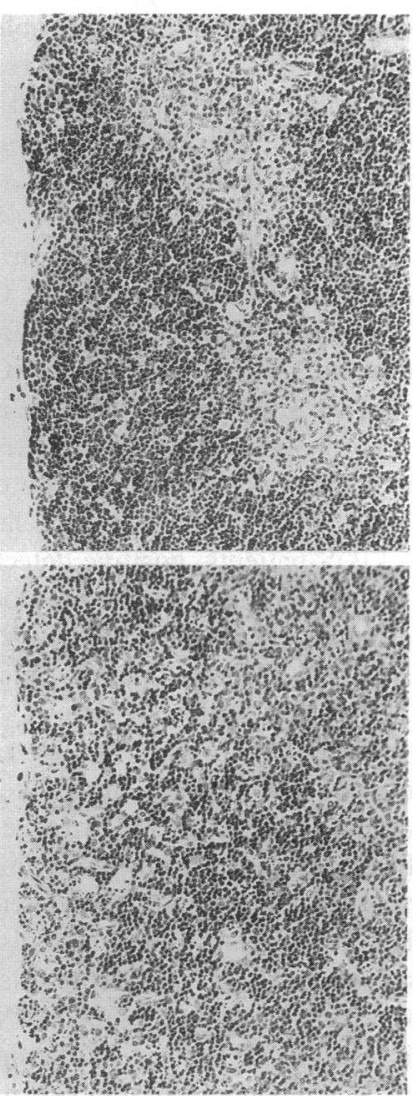

B

\section{MCMV}

in

Lung/SG

$(-) /(-)$

$(-) /(+)$
ANTI-CD3(-)
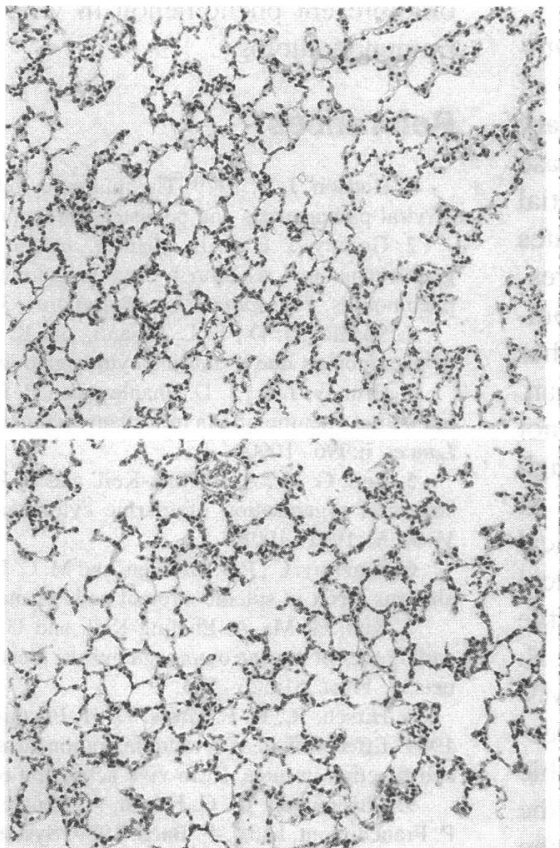

ANTI-CD3(+)
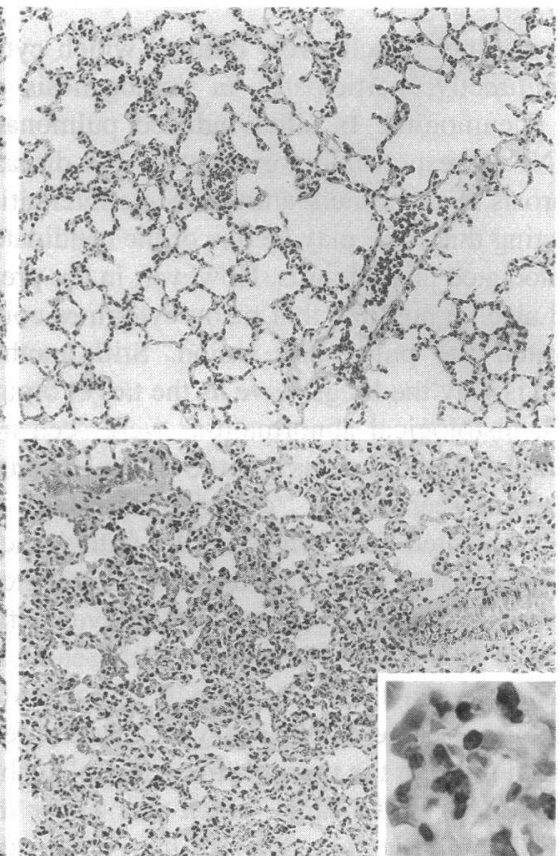

Figure 3. Histological findings of interstitial pneumonitis. (A) Histological examination in various organs at $48 \mathrm{~h}$ after anti-CD3 (20 $\mu \mathrm{g})$ injection (bottom) or not (top) in mice which had been inoculated with MCMV 4 wk earlier. Histological examination staining, original magnification: thymus, $\times 200$; spleen, $\times 100$; liver, $\times 100$; kidney, $\times 100$. $(B)$ Histological examinations of the lungs of mice, which were inoculated with $($ bottom) or without (top) MCMV $4 \mathrm{wk}$ ago. Mice were then injected with (right) or without (left) $20 \mu \mathrm{g}$ of anti-CD3 at $48 \mathrm{~h}$ before collecting the lungs. Histological examination staining, original magnification, $\times 170$. Inset, $\times 1000$. 
is one of the common risk factors in allogeneic organ transplantation. Previously, it had been explained that immunosuppression renders the host unable to control replication of the virus through a mechanism of reactivation or reinfection. However, recent studies on human CMV pneumonitis suggested that virus replication in the lung is unrelated to onset of CMV pneumonitis and that the host immune system participates in the pathogenesis of the disease $(4,15,16)$. This clinical concern was confirmed by the data on AIDS patients. $90 \%$ or more of patients with AIDS, whose $\mathrm{CD}^{+} \mathrm{T}$ cells in the blood are significantly decreased in number, exhibit evidence of CMV infection; $50 \%$ or more develop CMV viremia (17-19). Though manifestations of CMV disease in AIDS patients include retinitis, esophagitis, gastritis, hepatitis, and encephalitis, CMV pneumonitis is uncommon, in spite of the readily detectable infectious CMV in bronchoalveolar lavage fluid (20-22). In contrast to AIDS patients, positive detection of CMV in bronchoscopy specimen culture is always associated with CMV pneumonitis in the patients without AIDS (23). This discrepancy indicates that $\mathrm{CD}^{+} \mathrm{T}$ cells in the host play a role in the pathogenesis of CMV pneumonitis. Moreover, there is ample evidence that CMV infection occurs in bone marrow transplant recipients as an asymptomatic infection detectable by bronchoalveolar lavage, well before the occurrence of interstitial pneumonia (24). However, the progression of this infection after bone marrow transplantation to interstitial pneumonitis usually occurs in association with graft-versus-host disease, also suggesting that there is a role for $\mathrm{CD}^{+} \mathrm{T}$ cells in this pathogenesis. Though clinical efficacy of ganciclovir in CMV retinitis and gastrointestinal disease is well known, its therapeutic efficacy in the treatment of CMV pneumonitis after organ transplantation is controversial $(25,26)$. It is possible that syndromes such as retinitis and enteritis are due to the direct destructive effects of virus replication, whereas CMV pneumonitis may be mediated by cytokines but not by virus per se.

In this study, it was not conclusively defined which cytokine, directly or indirectly, participates in pathogenesis of MCMV-associated pneumonitis. In silica-induced pulmonary fibrosis in mice, TNF is responsible for onset of the disease (27). Pulmonary fibrosis is a chronic feature of acute interstitial pneumonitis, suggesting that TNF may be one of the candidates to cause MCMV-associated pneumonitis. However, in the present model, it would also be possible that many cytokines comprehensively generated the pulmonary lesion. Still another unanswered question is why the lungs serve as the target organ. As shown in Fig. 3, histological abnormalities were seen not only in the lungs but also in the thymus and the spleen. Though all of these three organs seem to be "cytokine-sensitive" in the mice persistently infected with MCMV, the pathological changes only in the lungs cause fatal reactions; the pathological changes in the thymus and the spleen are destructive to the organs but are not fatal to the host. Recently, Balthesen et al. (28) reported that the lungs are the major organ site of CMV latency. Although their experimental setting with neonal infection was different from those in the present study, it is plausible that low copies of MCMV in the lung, which was under the detection level of PCR amplification, activate the cells in the lung, causing the fatal reaction per se.

The present results demonstrate one of the features in the pathogenesis of persistent MCMV infection. Persistent MCMV infection primes the host immune system, either in an MCMVspecific or nonspecific fashion, resulting in the induction of a preactivated state of the host capable of releasing a supraphysiological amount of cytokines upon pan $\mathrm{T}$ cell activation by antiCD3 mAb. This may not be typical for murine CMV. Dudding et al. (29) reported that human CMV augments monokine mRNA expressions in infected monocytes. Similarly, human CMV enhances TNF- $\alpha$ gene expression (30). In both reports, cells exposed to human CMV require the second signal, such as PMA-mediated or LPS-mediated signal, respectively, to release a massive amount of cytokines. In our present experimental model, anti-CD3 mAb was used to activate pan T cells. We consider the possibility that massive cytokine release can occur after treatment with superantigens or even nominal antigens. If this is true, the secondary infection by other microbes during persistent CMV infection may trigger CMV-associated pneumonitis in the host. Moreover, the present results of MCMVassociated interstitial pneumonitis cast a concern about the selection of the use of immunosuppressive agents in clinical allograft transplantation. Though clinical efficacy of anti-CD3 mAb for ongoing allograft rejection episode is well established, it should be kept in mind that this mAb has the possibility to cause severe cytokine release syndrome, including interstitial pulmonary lesions in the allograft recipients with persistent CMV infection (Table I). Combined treatment of CsA with antiCD3 would reduce morbidity of cytokine release syndrome, even when allograft rejection is resistant to CsA. In this connection, it must be mentioned that anti-TCR mAb does not appear to induce the syndrome in the host persistently infected with MCMV, in contrast to anti-CD3 mAb.

How persistent MCMV infection enhances the sensitivity of the host to the cytokine production-inducing activity of antiCD3 is presently unknown. However, as virus-induced enhancement of cytokine gene expression was reported in influenza $\mathrm{A}$ virus $(31,32)$ and Coxsackie $B$ virus $(33)$, it is possible that enhanced cytokine production after $T$ cell stimulation is an omnipresent phenomenon in viral infection and virus-induced immunopathology.

\section{References}

1. Hudson, J. B. 1979. The murine cytomegalovirus as a model for the study of viral pathogenesis and persistent infections. Arch. Virol. 62:1-29.

2. Grundy, J. E., J. D. Shanley, and G. M. Shearer. 1985. Augmentation of graft-versus-host reaction by cytomegalovirus infection resulting in interstitial pneumonitis. Transplantation (Baltimore). 39:548-553.

3. Shanley, J. D., E. L. Pesanti, and K. M. Nugent. 1982. The pathogenesis of pneumonitis due to murine cytomegalovirus. J. Infect. Dis. 146:388-396.

4. Grundy, J. E., J. D. Shanley, and P. D. Griffith. 1987. Is cytomegalovirus interstitial pneumonitis in transplant recipients an immunopathological condition? Lancet. ii:996-1000.

5. Keil, G. M., A. Ebeling-Keil, and U. H. Koszinowski. 1987. Sequence and structural organization of murine cytomegalovirus immediate-early gene $1 . J$. Virol. 51:1901-1908.

6. Pomeroy, C., P. J. Hilleren, and M. C. Jordan. 1991. Latent murine cytomegalovirus DNA in splenic stromal cells of mice. J. Virol. 65:3330-3334.

7. Keil, G. M., A. Ebeling-Keil, and U. H. Koszinowski. 1987. Immediateearly genes of murine cytomegalovirus: location, transcripts, and translation products. J. Virol. 61:526-533.

8. Hirsch, R., R. E. Gress, D. H. Pluznik, M. Eckhaus, and J. A. Bluestone. 1989. Effects of in vivo administration of anti-CD3 monoclonal antibody on $T$ cell function in mice. II. In vivo activation of T cells. J. Immunol. 142:737-743.

9. Chantenoud, L., C. Ferran, A. Reuter, C. Legendre, Y. Gevaert, H. Kreis, P. Franchimont, and J.-F. Bach. 1989. Systemic reaction to the anti-T-cell monoclonal antibody OKT3 in relation to serum levels of tumor necrosis factor and interferon- $\alpha$. N. Engl. J. Med. 320:1420-1421.

10. Allerge, M.-L., P. Vandenabeele, M. Depierreux, S. Florquin, M. Deschodt-Lanckman, V. Flamand, M. Moser, O. Leo, J. Urbain, W. Fiers, and M. Goldman. 1991. Cytokine release syndrome induced by the 145-2C11 antiCD3 monoclonal antibody in mice: prevention by high doses of methylprednisolone. J. Immunol. 146:1184-1191. 
11. Kahan, B. D. 1989. Medical intelligence: cyclosporine. N. Engl. J. Med. 321:1725-1738.

12. Paul, L. C. 1989. Maintenance immunosuppression: cyclosporine. In Renal Transplantation. E. Milford, B. M. Brenner, and J. H. Stein, editors. Churchil Livingstone Inc., New York. 105-128.

13. Koga, Y., K. Tanaka, Y.-Y. Lu, M. Ohtsu, M. Sasaki, G. Kimura, and K. Nomoto. 1994. Priming of immature thymocytes to the CD3-mediated apoptosis by infection with murine cytomegarovirus. J. Virol. 68:4322-4328.

14. Tanaka, K., Y. Koga, X.-Y. Zhang, M. Sasaki, Y. Wang, G. Kimura, and K. Nomoto. 1993. Extensive apoptosis occurring in the thymus during accelerated rejection of cardiac allografts in presensitized rats. J. Immunol. 151:748-758.

15. Zaia, J. A. 1991. Pathogenesis of CMV-associated disease in 1990. Transplant. Proc. 23:1-4.

16. Forman, S. J. 1990. Bone marrow transplantation. Transplant. Proc 23:110-114.

17. Reichert, C. M., T. J. O'Leary, D. L. Levens, C. R. Simrell, and A. A. Macher. 1983. Autopsy pathology in the acquired immune deficiency syndrome. Am. J. Path. 112:357-382.

18. Pass, H. I., D. A. Potter, A. M. Macher, C. Reichert, J. H. Shellhammer, H. Masur, F. Ognibene, E. Gelmann, H. C. Lane, A. Fauci, and J. A. Roth. 1984 Thoracic manifestations of acquired immune deficiency syndrome. J. Thorac. Cardiovasc. Surg. 88:654-658.

19. Quinnan, G. V., H. Masur, A. H. Rook, G. Armstrong, W. R. Frederick, J. Epstein, J. F. Manischewitz, A. A. Macher, L. Jackson, J. Ames, et al. 1984 Herpes infections in the acquired immune deficiency syndrome. JAMA (J. Am. Med. Assoc.). 252:72-77.

20. Broaddus, C., M. D. Dake, M. S. Stulbarg, W. Blumenfeld, W. K. Hadley, J. A. Golden, and P. C. Hopewell. 1985. Bronchoalveolar lavage and transbronchial biopsy for the diagnosis of pulmonary infections in the acquired immunodeficiency syndrome. Ann. Intern. Med. 102:747-752.

21. Jacobson, M. A., and J. Mills. 1988. Serious cytomegalovirus disease in the acquired immunodeficiency syndrome (AIDS). Ann. Intern. Med. 108:585594.

22. Gallant, J. E., R. D. Moore, D. D. Richman, J. Keruly, R. E. Chaisson, and Zidovudine Epidemiology Study Group. 1992. Incidence and natural history of cytomegalovirus disease in patients with advanced Human Immunodeficiency Virus disease treated with zidovudine. J. Infect. Dis. 166:1223-1227.
23. Stover, D. E., M. B. Zaman, S. I. Hadju, M. Lange, J. Gold, and D. Armstrong. 1984. Bronchoalveolar lavage in the diagnosis of diffuse infiltrates in the immunosuppressed host. Ann. Intern. Med. 101:1-7.

24. Schmidt, G. M., D. A. Horak, J. C. Niland, S. R. Duncan, S. J. Forman, J. A. Zaia, and The City of Hope-Stanford-Syntex CMV Study Group. 1991 A randomized controlled trial of prophylactic ganciclovir for cytomegalovirus pulmonary infection in recipients of allogeneic marrow transplants. N. Engl. J. Med. 324:1005-1011.

25. Shepp, D. H., P. S. Dandliker, P. De Miranda, T. C. Burnette, D. M. Cederberg, L. E. Kirk, and J. D. Meyers. 1985. Activity of 9-[2-hydroxy-1(hydroxymethyl)ethomethyl]guanine in the treatment of cytomegalovirus pneumonia. Ann. Intern. Med. 103:368-373.

26. Reed, E. L., P. S. Dandliker, and J. D. Meyers. 1986. Treatment of cytomegarovirus pneumonia with 9-[2-hydroxy-1-(hydroxymethyl)ethomethyl]guanine and high-dose corticosteroids. Ann. Intern. Med. 105:214-215.

27. Piguet, P. F., M. A. Collart, G. E. Grau, A.-P. Sappino, and P. Vassalli. 1990. Requirement of tumor necrosis factor for development of silica-induced pulmonary fibrosis. Nature (Lond.). 344:245-247.

28. Balthesen, M., M. Messerle, and M. J. Reddehase. 1993. Lungs are a major organ site of cytomegalovirus latency and recurrence. J. Virol. 67:53605366.

29. Dudding, L., S. Haskill, B. D. Clark, P. E. Auron, S. Sporn, and E.-S. Huang. 1989. Cytomegalovirus infection stimulates expression of monocyteassociated mediator genes. J. Immunol. 143:3343-3352.

30. Smith, P. D., S. S. Saini, M. Raffeld, J. F. Manishewitz, and S. M. Wahl 1992. Cytomegalovirus induction of tumor necrosis factor- $\alpha$ by human monocytes and mucosal macrophages. J. Clin. Invest. 90:1642-1648.

31. Gong, J.-H., H. Sprenger, F. Hinder, A. Bender, A. Schmidt, S. Horch M. Nain, and D. Gemsa. 1991. Influenza A virus infection of macrophages: enhanced tumor necrosis factor- $\alpha$ (TNF- $\alpha$ ) gene expression and lipopolysaccharide-triggered TNF- $\alpha$ release. J. Immunol. 147:3507-3513.

32. Carding, S. R., W. Allan, A. McMickle, and P. C. Doherty. 1993. Activation of cytokine genes in $\mathrm{T}$ cells during primary and secondary murine influenza pneumonia. J. Exp. Med. 177:475-482.

33. Henke, A., C. Mohr, H. Sprenger, C. Graebner, A. Stelzner, M. Nain, and D. Gemsa. 1992. Coxsackie virus B3-induced production of tumor necrosis factor$\alpha$, IL-1 $\beta$, and IL-6 in human monocytes. J. Immunol. 148:2270-2277. 